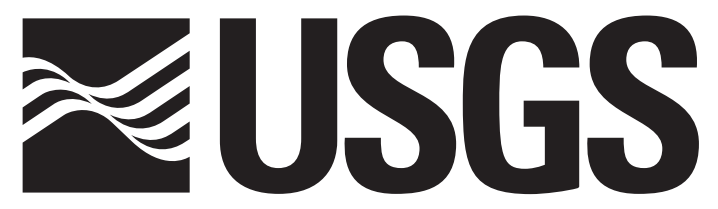

science for a changing world

\title{
Volcano Hazards in the Mount Jefferson Region, Oregon
}

Open-File Report 99-24

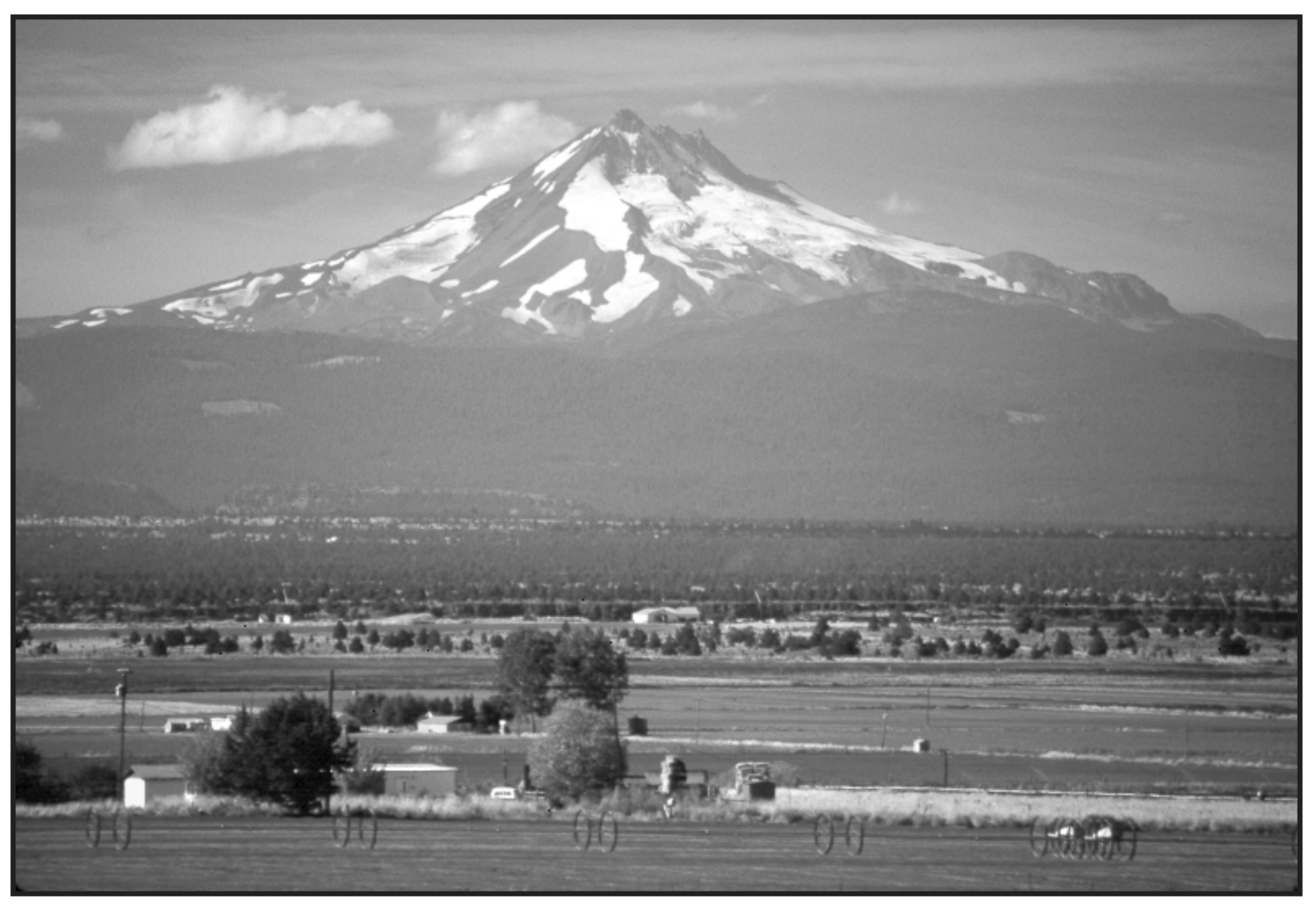

U.S. Department of the Interior U.S. Geological Survey 
U.S. Department of the Interior

U.S. Geological Survey

\section{Volcano Hazards in the Mount Jefferson Region, Oregon}

By Joseph S. Walder1, Cynthia A. Gardner1, Richard M. Conrey³, Bruce J. Fisher2, and Steven P. Schilling1

1. U.S. Geological Survey, Vancouver, Washington 98661

2. U.S. Geological Survey, Portland, Oregon 97216

3. Department of Geology, Washington State University, Pullman, Washington 99164

\section{Open-file Report 99-24}




\section{U.S. Department of the Interior \\ Bruce Babbitt, Secretary}

\section{U.S. Geological Survey \\ Charles G. Groat, Director}

This report is preliminary and has not been reviewed for conformity with U.S. Geological Survey editorial standards or with the North American Stratigraphic Code. Any use of trade, firm, or product names is for descriptive purposes only and does not imply endorsement by the U.S. Government.

To purchase USGS publications contact:

U.S. Geological Survey

Information Services

P.O. Box 25286

Denver, CO 80225

(303) 202-4210 


\section{Contents}

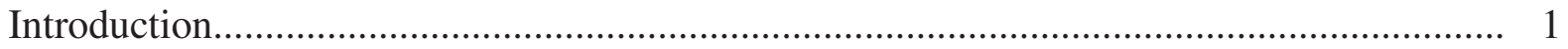

Hazardous phenomena in the Mount Jefferson region......................................................... 1

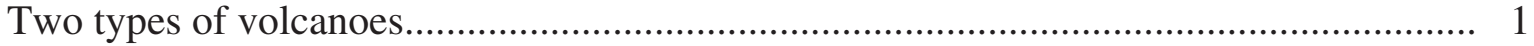

Hazardous phenomena at composite volcanoes................................................................ 2

Hazards related to explosive eruptions.................................................................... 2

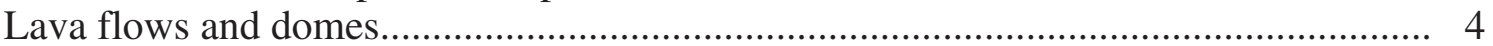

Debris avalanches and lahars............................................................................ 4

Hazardous phenomena at monogenetic volcanoes.......................................................... 5

Past events at Mount Jefferson map.......................................................................... 5

Volcano-hazard-zonation map.................................................................................... 6

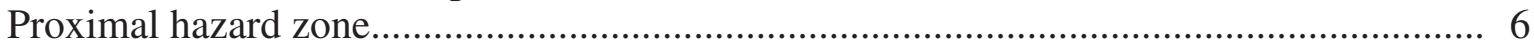

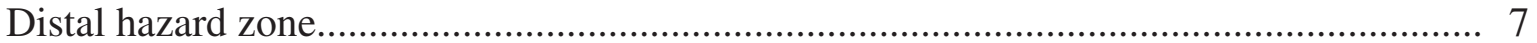

Breitenbush River Valley........................................................................................ 9

North Santiam River Valley.................................................................................... 9

Shitike Creek Valley................................................................................................ 10

Whitewater River Valley.......................................................................................... 10

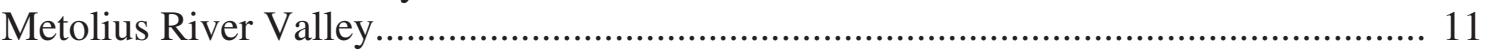

Regional lava-flow hazard zone.................................................................................. 11

Tephra hazard zone......................................................................................... 11

Hazard forecasts and warnings.................................................................................. 12

Protecting our communities and ourselves from volcano hazards...................................... 12

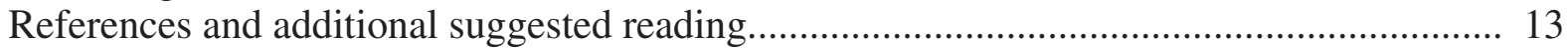

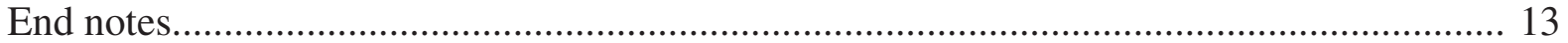

\section{Illustrations}

Plate 1. Volcano hazards in the Mount Jefferson Region, Oregon

In pocket

Proximal and distal hazard zones from an event at Mount Jefferson; regional hazard zones that could be affected by eruptions of monogenetic volcanoes.

Plate 2. Volcano hazards in the Mount Jefferson Region, Oregon In pocket

Map A. Lahar-inundation zone for areas downstream of Detroit Dam for the case in which the dam is breached.

Map B. Lahar-inundation zones for areas downstream of Pelton Dam for the case in which the Round Butte and Pelton dams are breached.

Map C. Regional tephra-fall maps.

Figure 1. Simplified sketch showing hazardous events at a volcano like Mount Jefferson... 3

Cover photo: Mount Jefferson from the east.

Lyn Topinka, U.S. Geological Survey 


\title{
Volcano Hazards in the Mount Jefferson Region, Oregon
}

\author{
By Joseph S. Walder, Cynthia A. Gardner, Richard M. Conrey, Bruce J. Fisher, and Steven P. Schilling
}

\section{Introduction}

Mount Jefferson is a prominent feature of the landscape seen from highways east and west of the Cascades. Mount Jefferson (one of thirteen major volcanic centers in the Cascade Range) has erupted repeatedly for hundreds of thousands of years, with its last eruptive episode during the last major glaciation which culminated about 15,000 years ago. Geologic evidence shows that Mount Jefferson is capable of large explosive eruptions. The largest such eruption occurred between 35,000 and 100,000 years ago, and caused ash to fall as far away as the present-day town of Arco in southeast Idaho. Although there has not been an eruption at Mount Jefferson for some time, experience at explosive volcanoes elsewhere suggests that Mount Jefferson cannot be regarded as extinct. If Mount Jefferson erupts again, areas close to the eruptive vent will be severely affected, and even areas tens of kilometers (tens of miles) downstream along river valleys or hundreds of kilometers (hundreds of miles) downwind may be at risk.

Numerous small volcanoes occupy the area between Mount Jefferson and Mount Hood to the north, and between Mount Jefferson and the Three Sisters region to the south. These small volcanoes tend not to pose the far-reaching hazards associated with Mount Jefferson, but are nonetheless locally important.

A concern at Mount Jefferson, but not at the smaller volcanoes, is the possibility that smallto-moderate sized landslides could occur even during periods of no volcanic activity. Such landslides may transform as they move into lahars (watery flows of rock, mud, and debris) that can inundate areas far downstream. The population at immediate risk in the Mount Jefferson region is small, but these residents as well as other people who visit the area for recreation and work purposes should be aware of the potential hazards. Probably the greatest concern in the Mount Jefferson region is the possibility that large lahars might enter reservoirs on either side of the volcano, namely, Detroit Lake to the west and Lake Billy Chinook to the east. Lahars entering these lakes could set up large waves that could overtop dams and possibly cause dam failure, with catastrophic effects downstream. Such events have very low probabilities but great potential consequences.

This report describes the kinds of hazardous geologic events that have occurred in the Mount Jefferson area in the past and shows, in the accompanying volcano-hazards-zonation maps, which areas will likely be at risk when hazardous events occur again in the future.

\section{Hazardous phenomena in the Mount Jefferson region}

The last eruption in the Mount Jefferson region occurred long before human habitation of the area. Moreover, the geologic history of Mount Jefferson is not well known [1]. Therefore, we rely on data from similar volcanoes around the world to gain a general idea of possible eruption scenarios and hazards. This is a reasonable method because similar types of events occur at many volcanoes, even though exactly which types of events occur and their relative frequencies and magnitudes vary from volcanic centers to volcanic center.

\section{Two types of volcanoes}

Two types of volcanoes are found in the Mount Jefferson region: composite and monogenetic.

Composite volcanoes erupt episodically over tens to hundreds of thousand of years and can display a wide range of eruption styles. Mount Jefferson is a composite volcano that has been active episodically for about 300,000 years. 
Monogenetic volcanoes typically erupt for only brief time intervals - weeks to perhaps centuries-and generally display a narrower range in eruptive behavior. Most monogenetic volcanoes are basaltic in composition, but just north of Mount Jefferson a few are of andesite and dacite composition-that is, with a relatively higher silica content (see inset figure 1). Over a time span of hundreds of thousands of years, these monogenetic volcanoes have built a broad upland areas (hundreds to thousands of square kilometers (miles)) of mostly basaltic lava flows and small volcanoes. Prominent basaltic volcanoes in the Mount Jefferson region include Olallie Butte, Potato Butte, Sisi Butte, and North and South Cinder Peaks. Fresh-looking basalt lava flows can be seen along the Cabot Creek, Jefferson Creek, and upper Puzzle Creek drainages. Hundreds more basaltic volcanoes form the High Cascades of central Oregon to the south of Mount Jefferson, as far as Crater Lake, 180 kilometers (110 miles) away.

\section{Hazardous phenomena at composite volcanoes}

All of the hazardous events depicted in the accompanying schematic illustration of a composite volcano (figure 1) have occurred at Mount Jefferson in the past and could occur in the future. Most are caused by eruption of molten rock, or magma, but some, like debris avalanches and lahars, can occur without eruptive activity.

\section{Hazards related to explosive eruptions}

As magma nears the surface, gases dissolved in the magma are released. Rapid release can make the magma frothy and propel it upward from the vent in a rush of expanding hot gas. The resulting solidified rock fragments, called tephra, range in size from large bombs $(6 \mathrm{~cm}$ to 1 meter ( 2 inches to 3 feet) or more in diameter) to ash (sand size or finer). Large tephra particles fall back to the ground within a few kilometers (miles) of the vent. Particles that move on arcs like artillery shells are called ballistic projectiles. Their range rarely exceeds 5 kilometers ( 3 miles) from the eruptive vent, and most projectiles are less than one meter (3 feet) across. The chief hazard from ballistic projectiles is from direct impact. Large projectiles may still be quite hot when they land, and can start fires if they land near combustible materials.

Relatively small tephra particles can rise more than ten kilometers (30,000 feet) upward and be carried downwind (figure 1). The particles gradually fall from the ash cloud and can blanket areas for tens to hundreds of kilometers (tens to hundreds of miles). Tephra fall seldom directly threatens life except within a few kilometers of the eruptive vent, but ash suspended in the air can irritate the eyes and respiratory system, especially in infants, the elderly, and the infirm, and prolonged inhalation of certain kinds of tephra can cause chronic lung disease. Perhaps more hazardous are the indirect effects. Tephra plumes can create tens of minutes to hours of darkness, even on sunny days, as they pass overhead, and tephra fall can reduce visibility on highways. In addition, deposits of tephra can short-circuit or break electric transformers and power lines, especially if the tephra is wet, as well as cause roofs of buildings to collapse. (In several historical examples, accumulation of more than 10 centimeters (4 inches) of wet tephra caused roofs to collapse, although the precise critical thickness depends upon the structural soundness of the roof. In the Pacific Northwest, most houses are built to sustain heavier snow loads.) Tephra can clog filters and increase wear on vehicle engines. Tephra clouds commonly generate lightning that can interfere with electrical and communication systems and start fires. Finally, and perhaps most importantly, even small, dilute tephra clouds pose great hazards to aircraft that fly into them.

Lessons learned during the 1980 eruption of Mount St. Helens in downwind Washington communities such as Yakima, Ritzville, and Spokane are now applied throughout the Pacific Northwest and elsewhere to prepare governments, businesses, and citizens for future tephra falls. These three communities experienced significant disruptions in transportation, business activities, and community services as a result of fallout of from 5 to 80 millimeters (1/4 to 3 inches) of tephra. The greater the amount of tephra that fell, the longer a community took to recover. As 


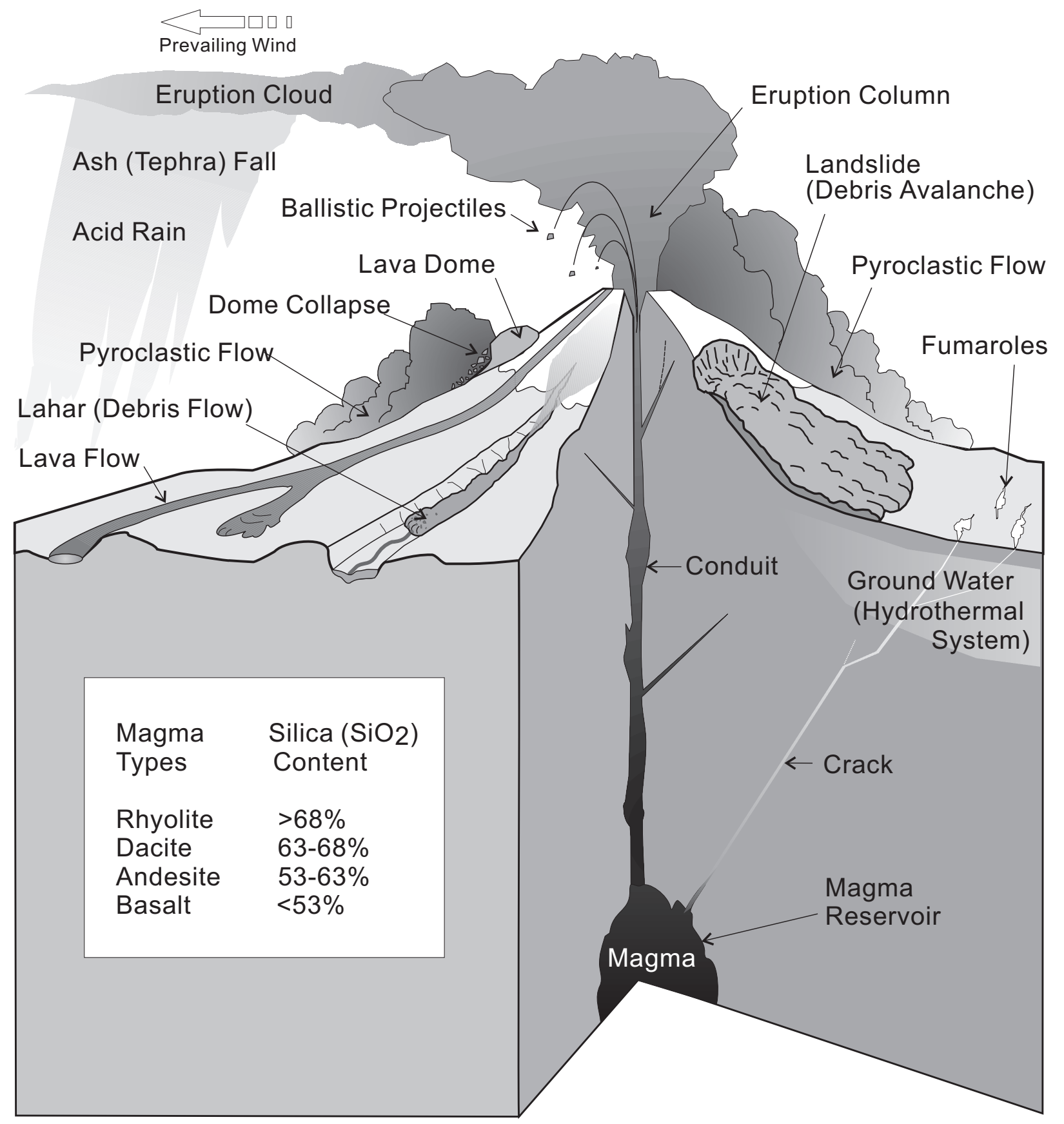

Figure 1. Simplified sketch showing hazardous events at a volcano like Mount Jefferson. Events such as lahars and landslides (debris avalanches) can occur even when the volcano is not erupting. Inset box shows classification of magma types on the basis of silica content. Illustration by Bobbie Myers, modified from USGS Fact Sheet 002-97.

perceived by residents, tephra falls of less than $5 \mathrm{~mm}$ (1/4 inch) were a major inconvenience, whereas falls of more than $15 \mathrm{~mm}(2 / 3 \mathrm{inch})$ constituted a disaster. Nonetheless, all three communities recovered to nearly normal activities within two weeks.
Sometimes the mixture of hot gases and volcanic rock particles produced by an explosive eruption is denser than air. Instead of rising above the vent to produce tephra, the mixture behaves like a fluid and flows downslope over the ground surface. If the mixture is made up mostly of rock 
particles, it has a high density and topography controls its path, just as topography controls the flow of water. Such a gas-poor mixture is called a pyroclastic flow. If the mixture is made up mostly of gas, with only a small proportion of rock fragments, it has a lower density and its path is weakly influenced by topography. Such a gas-rich mixture is called a pyroclastic surge.

Pyroclastic flows and surges often occur simultaneously, and both are exceedingly hazardous. They move at such high speeds that escape from them is difficult or impossible. Pyroclastic flows typically sweep down the flanks of volcanoes at speeds of 50 to 150 kilometers per hour (30 to 90 miles per hour). Temperatures in pyroclastic flows are usually more than 300 degrees Celsius (570 degrees Fahrenheit). Owing to their high density, high velocity, and high temperature, pyroclastic flows can destroy all structures and kill all living things in their paths by impact, burial, and incineration. The effects of pyroclastic surges may be less severe, because of lower densities and temperatures, but are still usually destructive and lethal. People and animals caught in pyroclastic surges may be killed by direct impact by rocks, severe burns, or suffocation.

\section{Lava flows and domes}

Lava is magma that reaches the Earth's surface nonexplosively. Depending on its viscosity and rate of discharge, lava will form a bulbous lava dome over the vent or a lava flow that extends several to more than 10 kilometers (6 miles) downslope. Observations of lava flows at similar volcanoes elsewhere suggest that lava flows at Mount Jefferson would move down valleys as tongues of fluid lava a few to tens of meters (10-30 feet) thick encased in a thick cover of hardened lava rubble. Such lava flows can destroy all structures in their paths and because of their intense heat may start forest fires.

However, because lava flows advance so slowly they seldom endanger people. Lava domes, on the other hand, may pose a far greater hazard. Lava domes that grow on steep slopes are typically unstable and collapse repeatedly as they grow higher and steeper, forming fast-moving pyroclastic flows.

\section{Debris avalanches and lahars}

The slopes of a volcano may become unstable and fail, generating a rapidly moving landslide called a debris avalanche. This instability may be caused by magma forcing its way into a volcano, pushing aside older rocks. The best-known historic example of this type of magmatically induced debris avalanche occurred in 1980 at Mount St. Helens. A volcano's slopes can also fail without the direct involvement of magma. Stability slowly declines as slopes become over-steepened by glacial erosion or as the strength of the rock is reduced by hot, acidic waters of a hydrothermal system. The acidic waters chemically alter rock to clay and other minerals. Like a house infested with termites, the altered rock gradually weakens and may collapse under its own weight, thereby generating a debris avalanche. Non-magmatically induced debris avalanches occur frequently at volcanoes and can be especially dangerous because some large ones may occur without any warning. Earthquakes, steam explosions, and intense rainstorms can also trigger debris avalanches from parts of a volcano that have already been weakened by glacial erosion or hydrothermal activity.

A debris avalanche can travel tens of kilometers (tens of miles) and can attain speeds in excess of 160 kilometers per hour (100 miles per hour); the larger the avalanche, the farther it can move. Avalanche path is strongly controlled by topography. Structures and objects in the avalanche path will likely be destroyed by impact and incorporated into the avalanche. The resulting deposit is usually a few meters (yards) to hundreds of meters (hundreds of yards) thick, with a hummocky surface. Deposits of a large debris avalanche can block the mouths of tributary valleys and cause lakes to form. When impounded water spills over the blockage, it can quickly cut a channel and cause catastrophic lake drainage, generating a flood or lahar ( a moving slurry of water and sediment much like flowing concrete). This may occur hours to months after formation of the impoundment.

Whatever their origin, debris avalanches commonly contain enough water or incorporate enough water, snow or ice to transform into lahars. Lahars usually move at speeds of tens of 
kilometers (tens of miles) per hour, and destroy or damage everything in their paths by impact or burial. Lahars follow river valleys and may fill the valleys to depths of 30 meters (100 feet) or more. Reservoirs in valleys downstream from a volcano may be partly or wholly filled by lahars moving down valley, so if the water level of a reservoir is not lowered in time, water displaced by a lahar could cause floods farther downstream and may endanger the dam. Lahars can also form by other mechanisms. Pyroclastic flows can incorporate and melt enough snow and ice to generate lahars. Relatively small lahars can also be generated by outburst floods released suddenly from glaciers, by failure of

glacial-moraine dams that impound small lakes, or by heavy rain remobilizing loose fragmental material on the flanks of volcanoes.

Lahars may cause problems long after the original event has ceased. Once lahars fill stream channels with sediment, channels begin to erode new paths. In such situations, channels can become unstable and shift rapidly as sediment is moved farther downstream. Also, because channels become filled with sediment, they can convey less water and susceptibility to flooding increases. Examples from many volcanoes, including Mount St. Helens, show that such effects can persist for years to decades.

\section{Hazardous phenomena at monogenetic volcanoes}

Monogenetic volcanoes are usually of basaltic composition (figure 1) and typically erupt less explosively than do composite volcanoes, so their eruption effects are spatially limited. A few monogenetic volcanoes in the Mount Jefferson area southwest of Olallie Butte are small dacite domes. Emplacement of future dacite domes may involve a small explosive phase, and collapse of dome margins could form small-volume pyroclastic flows and lahars. Nonetheless, lava flows constitute the primary hazard associated with monogenetic volcanoes in the Mount Jefferson area. Lava flows can destroy everything in their paths by burial or incineration, but generally travel slowly enough that they are not life-threatening to most humans or wildlife. Hazards associated with tephra fall are generally restricted to areas within a few kilometers (1-2 miles) downwind of an eruptive vent. Floods or lahars may be caused by lava flows interacting with winter snowpack, or by partial collapse of lava flow fronts or dome margins. Perhaps the most dangerous events at basaltic volcanoes occur when rising magma interacts explosively with surface water or shallow ground water, producing steam explosions and pyroclastic flows that sweep rapidly outward several kilometers (several miles) from the vent. However, deposits associated with such events have not been recognized in the Mount Jefferson region.

\section{Past events at Mount Jefferson}

Details regarding eruptive events at Mount Jefferson are poorly known for several reasons. The last major eruption occurred a long time ago, and since that time the volcano has been covered by large glaciers that eroded away many deposits, including much of the lahar record. Furthermore, we know the dates of only a few of the eruptive products that have been preserved. Nonetheless, although many details are unknown, we do know that Mount Jefferson has a history that extends back for several hundred thousand years and that it has exhibited a wide range of eruptive styles-from highly explosive events to lava flows and lava domes.

What we do know of the history of Mount Jefferson can be summarized as follows. The oldest rocks at Mount Jefferson are about 300,000 years old and crop out on the west-southwest side of the volcano. The next oldest rocks are found in the Park Butte area and are about 150,000 years old. Sometime between 35,000 and 100,000 years ago, a very large explosive eruption occurred. Tephra from this eruption has been found as far away as southeast Idaho, and within 20 kilometers (12 miles) of volcano is locally 2 meters (6 feet) thick. During this same broad period of time, pyroclastic flows moved down two drainages on Mount Jefferson (Whitewater River on the east side and Whitewater Creek on the west side).

Most of the cone (upper 1000 meters) of Mount Jefferson is less than 100,000 years old, 
with much of it younger than the explosive event described above. The upper cone is composed largely of dacite lava flows and domes, many of which appear to have been emplaced when glaciers on the volcano were much larger than at present. It is likely that during growth of the domes, material was shed off to form pyroclastic flows and lahars, but if so, that record has been largely removed by glacial erosion.

During the last few centuries, several small lakes were formed on the flanks of Mount Jefferson when small tributary valleys became dammed by glacial moraines (ridges of sediment left behind by glaciers). Several of these moraines have breached during the 20th century, producing local floods and small lahars.

The youngest lava flows in the Mount Jefferson area are basaltic lava flows from Forked Butte and an unnamed butte south of Bear Butte. Both of these flows postdate the large eruption of Mount Mazama (Crater Lake) of about 7,600 years ago.

\section{Volcano-hazard-zonation map}

The accompanying volcano-hazard-zonation maps show areas most likely to be affected by future hazardous geologic events in the Mount Jefferson region. Individual events typically affect only part of a hazard zone. The location and size of an affected area will depend on the location of the erupting vent or landslide, the volume of material involved, the snow and ice conditions around and down slope from the vent, and the character of an eruption, especially its explosivity.

Potentially hazardous areas around Mount Jefferson are divided into proximal and distal hazard zones depending on distance from the volcano. Some zones are subdivided further on the basis of their relative degree of hazard.

Hazard-zone boundaries are drawn on the basis of: (1) the magnitude of past events at the volcano, as inferred from deposits; (2) mathematical models that use calibrations from other volcanoes to forecast the probable extent of future pyroclastic flows, debris avalanches, and lahars; and (3) our experience and judgment derived from observations and understanding of events at other similar volcanoes. A regional hazard zone for lava flows from volcanoes is also shown on plate 1. Maps of the Pacific Northwest depicting hazard zones for tephra falls from all Cascade composite volcanoes are shown on plate 2.

Although the maps show sharp boundaries for hazard zones, the degree of hazard does not change abruptly at these boundaries. Rather, the hazard decreases gradually as distance from the volcano increases and, for lahars, decreases more rapidly as elevation above valley floors increases. Areas immediately beyond outer hazard zones should not be regarded as hazard-free, because the boundaries can only be located approximately, especially in areas of low relief. Too many uncertainties exist about the source, size, and mobility of future events to locate the boundaries of zero-hazard zones precisely.

It is almost impossible to estimate the probability of future eruptions at Mount Jefferson owing to the lack of eruptive activity in the last 15,000-20,000 years, the imprecise dating of older deposits, and the fact that the geologic record generally preserves only the largest eruptive events. At other Cascade volcanoes where there is a better record of the last 12,000 to 15,000 years, long periods of dormancy have occurred between eruptive episodes. For example, Mount St. Helens was dormant from 10,000 years ago until 4,000 years ago — a period of 6,000 years - and Mount Hood was dormant from about 15,000 years ago until 1,500 years ago - a period of nearly 14,000 years. Our knowledge of volcanoes is too limited to know how long a dormant period at any given volcano can last. Because the consequences of renewed activity could be severe, we continue to monitor Mount Jefferson for signs of restlessness.

\section{Proximal hazard zone}

The proximal hazard zone includes areas immediately surrounding Mount Jefferson. This zone, which, depending on local topography, extends 8 to 16 kilometers (about 5-10 miles) outward from the summit, delineates the area subject to several types of rapidly moving, 
devastating phenomena including pyroclastic flows and surges, lava flows, and ballistics [2]. During periods of volcanic unrest or during an eruption, these are areas to be avoided because events often unfold too quickly for humans to escape harm. Debris avalanches and lahars originate in the proximal area and small events may be restricted to this zone. However, larger debris avalanches and lahars will move off the volcano and far down river valleys. The extent of these larger lahars constitute the distal hazard zones.

Failure of glacial moraine dams that impound high-altitude lakes on Mount Jefferson could release floods of water and debris. The major impact of such events would be restricted to the proximal hazard zone, but parts of distal hazard zones adjacent to streams might also be inundated. Several moraine-dam failures have occurred during the 20th century and inundated parts of Jefferson Park and part of the Jefferson Creek drainage below Waldo Glacier [3].

\section{Distal hazard zones}

Explosive eruptions or large debris avalanches in the proximal hazard zone can generate lahars of sufficient volume to travel tens of kilometers (tens of miles) from source areas. The hazard-zonation map shows that distal hazards from such events are concentrated in the valleys of the South Fork Breitenbush River and the North Santiam River on the west side of Mount Jefferson, and in the valleys of the Whitewater River, Metolius River, and Shitike Creek on the east side. Debris avalanches and lahars will tend to funnel into these valleys as they leave the slopes of Mount Jefferson within the proximal hazard zone.

Geologic evidence of lahar-producing events at Mount Jefferson is scant and provides little guidance with which to forecast the extent of lahars that may be produced by future eruptions or debris avalanches. We therefore use a mathematical technique calibrated with data from other volcanoes [4] to estimate the extent of distal inundation by future lahars of various volumes. For each of the major valleys draining
Mount Jefferson, we computed three nested distal hazard zones that depict anticipated inundation by hypothetical "design" lahars of three different volumes. The largest design lahar reflects our estimate of the largest debris avalanche (500 million cubic meters, or about 650 million cubic yards) that might descend suddenly from Mount Jefferson [4]. A debris avalanche of this size would entail wholesale failure of a large part of the volcano's upper flanks and would require either complete transformation of the debris avalanche into a lahar or considerable incorporation of down-valley material to achieve a lahar volume of 500 million cubic meters (650 million cubic yards). Such an event would probably occur in conjunction with volcanic activity that would be detected by monitoring; however, we cannot rule out the low probability that some large flank failures could be triggered by mechanisms other than magmatic intrusion (for example, gravitational failure due to hydrothermal alteration slowly weakening summit rocks).

The intermediate and smallest design lahars are more typical lahar volumes for a moderate eruption or for a debris avalanche without warning. The intermediate-sized design lahar has a volume of 100 million cubic meters (about 130 million cubic yards), and the smallest design lahar has a volume of 20 million cubic meters (about 25 million cubic yards). The distal hazard zone for the smallest design lahar depicts anticipated inundation areas from events that could occur during small eruptive events or steam explosions; it also depicts inundation areas from events that occur without eruptive activity at the volcano and for which there would be no precursory warning. These include rain-on-snow events remobilizing loose sediment on the slopes, outburst floods, and small debris avalanches or rockslides.

A special case exists for the valleys of Shitike Creek (north and east of Mount Jefferson) and Minto Creek (south and west of Mount Jefferson). For both cases we show lahar-inundation zones for only the smallest design lahar, even though we anticipate these areas would be affected only during the largest magnitude events. Neither Shitike Creek nor Minto Creek heads directly on Mount Jefferson. Debris avalanches or pyroclastic 
flows entering these valleys would have to overtop divides about 200 to 250 meters (660 to 820 feet) high. Based on experience at Mount St. Helens during the 1980 eruptions, only extremely large events would be able to overtop such high divides, and only a small percentage of the total debris volume would actually make it over. Thus we suggest that the 20 million cubic meter (25 million cubic yard) design lahar represents the largest probable lahar for Shitike and Minto Creeks. Because only extremely large debris avalanches at Mount Jefferson are likely to affect these drainages, the probability of a 20 million cubic meter (25 million cubic yard) lahar affecting either drainages is equally as small as the probability of the largest debris avalanche happening at Mount Jefferson.

Because large lahars are less likely to occur than small lahars, the nested distal hazard zones show that the likelihood of lahar inundation decreases as distance from the volcano and elevation above the valley floors increase. No lahar as voluminous as any of the design lahars has occurred in the past 15,000 years [5], so lahars of such magnitudes have an annual probability of less than 1 in 15,000. However, this probability would increase immediately if restless activity were detected at the volcano, with the inundation area of the smallest design lahar having the highest probability. Small lahars that result from phenomena such as moraine-dam failures or rock slides are much more likely to occur (annual probability about 1 in 1000 to 1 in 100 in potentially affected valleys), but are apt to inundate only parts of the smallest design hazard zone immediately adjacent to streams (in other words, an area smaller than that represented by the smallest design lahar). In such instances, some debris may travel farther downstream but stay mostly confined within stream banks.

The distal hazard zones for lahars and debris avalanches have been depicted on the map in two different ways, depending upon assumptions used in considering the effects of the large reservoirs on the west and east sides of the volcano. In truth, we only have a rough idea how the reservoirs would actually be affected by lahar entry. Based on field and experimental data [6], we suggest the following scenarios will apply:
1. If lahar volume is much less than both reservoir volume and available storage (the difference between maximum capacity and actual volume at any given time), entry of the lahar into the reservoir will probably generate fairly small-amplitude waves that propagate rapidly across the lake, then a slow rise in lake level, with the lahar being completely contained within the lake basin. This is what happened when a lahar entered Swift Reservoir near Mount St. Helens in 1980.

2. If lahar volume exceeds maximum available storage, then the dam will certainly be overtopped owing to rising water level if not by wave action. Whether the dam subsequently fails is uncertain. An overtopped earthen dam, such as Round Butte Dam, which impounds Lake Billy Chinook, would likely be eroded by overflowing water and would probably be breached if the overflow were sufficiently sustained. A concrete dam, such as Detroit Dam, which impounds Detroit Lake, should be more resistant, but would still be at risk of failure.

3. Lahars with volumes less than maximum available storage may still cause overtopping and possible failure of dams owing to large waves that travel across the lake and run up against the dam face. The amount of runup depends in a complicated way on wave shape and amplitude, lake depth, slope of the dam face, lahar volume, lahar speed, and perhaps other factors. However, this scenario also strongly depends upon the water level in the reservoirs at the time of lahar entry.

If a dam fails, flood magnitude would strongly depend on the amount of water in the reservoir, and would be greatest if no drawdown had preceded lahar emplacement. In the case of Detroit Lake, the amount of available water would be seasonally dependent as available storage is strongly linked to flood control.

The map on plate 1 depicts distal-hazard zones, determined by a semi-empirical mathematical modeling technique [4], assuming that lahars are completely contained behind Detroit Dam and Round Butte Dam. This is almost certainly correct for the smallest design lahar, but almost certainly incorrect for the larger design lahars unless the reservoirs have been significantly drawn down beforehand. Maps A and B on plate 2 depict distal 
hazard zones downstream of these dams for lahars not contained behind Detroit Dam and Round Butte Dam. The inundation areas for these large events were also determined using the same mathematical modeling technique as above, but implicitly assuming that the dams and reservoirs provide no resistance to lahar movement. Maps A and B provide an admittedly rough estimate of inundation hazard zones, because the calculations [4] account for the volume of the lahar but not that of the water impounded behind the dams. Dam operators (the US Army Corps of Engineers for Detroit Dam, and Portland General Electric for Round Butte Dam) have constructed maps of probable flood inundation areas in the event of dam failure, but these maps account for only the water impounded behind the dams and not the volume of potential lahars.

\section{Breitenbush River Valley}

The South Fork Breitenbush River drains part of the north and northwest slopes of Mount Jefferson, and flows into the north side of Detroit Lake (a reservoir with a storage capacity of about 560 million cubic meters, or 455 thousand acre-feet, impounded behind Detroit Dam, a concrete structure.) Debris avalanches from Mount Jefferson directed a bit west of north, into Jefferson Park, would enter this drainage basin. Calculations using a mathematical technique for estimating lahar inundation area [4] show that lahars in this drainage of volume less than about 4 million cubic meters (5.2 million cubic yards) would stop short of Detroit Lake. Larger lahars would enter Detroit Lake, which is used for flood control and whose level varies greatly during the year [7]. The typical operating level (so-called maximum conservation pool) of the lake from May through August, when the lake is heavily used for recreational purposes, leaves a freeboard of about $1.7 \mathrm{~m}$ (5.5 feet) and an available storage of about 23 million cubic meters $(19,000$

acre-feet). The lake is drawn down from September through November to a level at which the freeboard is about 36 meters (110 feet) and the available storage is about 370 million cubic meters (300,000 acre-feet), and held at this level until February, when it is allowed to start refilling. Even our smallest design lahar, at 20 million cubic meters, might generate waves that would overtop the dam during summer if the lake were not lowered in advance. In contrast, the same lahar entering Detroit Lake during winter, with the lake at its lowest level, would almost certainly be contained. Indeed, even a 100-million-cubic meter-lahar would probably be contained during winter. A 500-million-cubic-meter lahar-the largest modeled lahar-would cause the dam to be overtopped and perhaps breached unless the lake had been significantly drawn down. Towns downstream of Detroit Lake that could be inundated by large lahars or dam-failure floods include Niagara, Mill City, and perhaps Stayton.

\section{North Santiam River Valley}

Whitewater Creek, Russell Creek, and Milk Creek drain the west slopes of Mount Jefferson and enter the North Santiam River, which flows into the east side of Detroit Lake. The North Santiam River continues below Detroit Dam. Lahars in this drainage of volume less than about 3 million cubic meters (4 million cubic yards) will stop short of Detroit Lake. Larger lahars will enter Detroit Lake and behave essentially the same as those entering the lake via the South Fork Breitenbush River, as described above.

A lahar could also enter the North Santiam River via Minto Creek, southwest of Mount Jefferson. Although it does not head on Mount Jefferson proper, the headwaters of Minto Creek are within the proximal hazard zone such that very large pyroclastic flows or very large debris avalanche could overtop the ridge southeast of Grizzly Peak. Any debris avalanche entering Minto Creek drainage would have to overtop a roughly 200 meter $(660 \mathrm{ft}$ ) high divide. Based on experience at Mount St. Helens during the 1980 eruptions, this is possible but very unlikely except for the largest of debris avalanches. The amount of debris entering Minto Creek would probably be a small fraction of the total. Thus we have shown the inundation area for a 20 million cubic meter lahar, and suggest this is a reasonable estimate of 
the maximum lahar that could move along this path.

Evidence has recently been discovered of prehistoric lahars that reached the site of present-day Salem about 100,000 years ago [5]. We presume these lahars originated at Mount Jefferson during an eruption and traveled along the valley of the North Fork River. However, we know little about the condition of the drainage basin at that time (for example, whether river level was near or at present river level) or much about the volume of glacier ice on the mountain other than that it was probably much greater than now. Our models suggest that under present conditions, it would take a lahar with a volume in excess of 1 cubic kilometer (1.3 billion cubic yards) to reach Salem. In our opinion, it would be extremely difficult to generate a lahar of such volume from a single instantaneous event (a single avalanche event or single explosive event). In the case of long-lived explosive events or multiple dome collapse events, it may be possible to shed so much debris into the river drainage to eventually cause flooding far beyond the limits shown for the largest design lahar. It may also be possible to inundate much larger areas than those shown if dam failure occurred as the result of a large lahar entering Detroit Lake at a time when water level was high.

\section{Shitike Creek Valley}

Shitike Creek heads in the area between Mount Jefferson and Olallie Butte to the north, then flows to the east toward the town of Warm Springs, beyond which it flows into the Deschutes River. Although it does not head on Mount Jefferson proper, Shitike Creek, like Minto Creek on the west side, could be susceptible to inundation by very large debris avalanches that could overtop a 250 meter (800 feet) ridge north of Jefferson Park. However, like Minto Creek, only a small fraction of the total avalanche volume would probably impact Shitike Creek. Thus, we have shown the inundation area for a 20-million-cubic-meter-lahar (25 million cubic yards), and suggest this is a reasonable estimate of the largest lahar that could enter Shitike Creek owing to an extremely large northward-directed debris avalanche from Mount Jefferson. Such an event could affect the town of Warm Springs, but we stress that an event of this magnitude has very low probability (annual probability much less than 1 in 15,000).

\section{Whitewater River Valley}

The Whitewater River drains the Whitewater Glacier and northeast slopes of Mount Jefferson, and is also fed by Milk Creek (not the same Milk Creek as on the west side of the mountain). All three hypothetical lahars considered in our assessment would move along the Whitewater River valley to the confluence with the Metolius River. Any lahar in the Whitewater River valley of volume greater than about 4 million cubic meters (5 million cubic yards) would reach Lake Billy Chinook, a reservoir with a capacity of about 660 million cubic meters $(535,000$ acre-feet) impounded behind Round Butte Dam, an earth-and-rock fill structure which is operated by Portland General Electric for hydropower generation [7]. The dam is operated with a freeboard of about $8 \mathrm{~m}$ (25 feet) and an available storage of about 165 million cubic meters $(135,000$ acre-feet). The smallest volume design lahar (20 million cubic meters, or 26 million cubic yards) would certainly generate waves in the reservoir, but it seems unlikely that the dam would be overtopped. The intermediate volume lahar (100 million cubic meters, or 130 million cubic yards) may cause an overtopping wave and the largest lahar (500 million cubic meters, or 650 million cubic yards) would almost certainly cause the dam to be overtopped and breached, generating large floods downstream, if lake levels were not lowered beforehand. Immediately downstream of Round Butte Dam, on the Deschutes River, is Simtustus Lake, a reservoir impounded behind Pelton Dam and also operated for hydropower. Floods caused by breaching of Round Butte Dam would probably overtop Pelton Dam and cause this dam to fail as well, sending large flood waves down the Deschutes River. Warm Springs, a city at the confluence of Shitike Creek and the Deschutes River, would be affected by such a flood wave. 


\section{Metolius River Valley}

Jefferson Creek and Parker Creek drain the southeast flank of Mount Jefferson and enter the Metolius River, which flows into Lake Billy Chinook. Lahars in this drainage of volume less than about 20 million cubic meters (26 million cubic yards) will stop short of Lake Billy Chinook. Larger lahars will enter the lake and behave essentially the same as those originating in the Whitewater River valley, as described above.

\section{Regional lava-flow hazard zone}

The regional lava-flow hazard zone outlined on the hazard map is the area affected by lava flows and near-vent explosive material from relatively short-lived eruptions from monogenetic volcanoes. The zone was defined by first determining the distribution of vents and lava flows less than 2 million years old. (There are a few exceptions to the rule. For example, Battle Axe Mountain, located about 15 kilometers (9 miles) north of the town of Detroit, is thought to be less than two million years old, yet is surrounded by terrain older than two million years and is thus excluded from this zone.) The vast majority of vents in this zone are basaltic; a few are dacite lava domes. We assume that future eruptions will occur within this zone As basaltic lava flows generally travel no farther than about 15 kilometers ( 9 miles) from their source vents, we locate the hazard boundary either 15 kilometers (9 miles) downslope from where vents may open, or where topographic features would probably stop or divert lava flows. Thus the zone juts out slightly in river valleys not already occupied by hazard zones from lahars. The regional lava-flow hazard zone encompasses land that is largely unpopulated, but which contains important infrastructure, most notably power lines.

The area immediately north of Mount Jefferson contains several domes younger than two million years of age of dacitic rather than basaltic composition. If new dacite domes should form in this area, it is possible that small explosive eruptions may accompany their growth and that pyroclastic flows might be generated by rock avalanches from the margins of the growing domes. However, domes formed here would being extruded on very gentle slopes, such that any pyroclastic flows or lahars formed by collapse of the dome margins would probably be restricted to the regional lava-flow hazards zone.

It is impossible to determine annual probabilities from vent distributions over the last 2 million years, because many of the older vents have since been buried by younger lava flows. Therefore, annual probabilities are based on the record since the last major ice age, about 12,000 years ago. Since that time there have been four eruptive episodes. Two of these involved vents very near each other that erupted at about the same time. Such a frequency suggests an average annual probability of about 1 in 4,000 to 1 in 3,000 . However, because only a relatively small area (generally less than 1 percent) of the regional lava-flow hazard zone is affected during any given eruptive episode, and because large areas within the zone have not been affected by renewed volcanism for about 1 million years, the annual probability of any point in the zone being affected is much less than the average annual probability and is more on the order of 1 in 1,000,000 to 1 in 300,000 .

\section{Tephra hazard zone}

Even small thicknesses of tephra can profoundly disrupt social and economic activity over broad areas. The thickness of tephra necessary to cause buildings to collapse depends on construction practices and whether the tephra is wet or dry. Eruptions of Mount Jefferson as well as of more distant volcanoes in the Cascade Range, are all sources of potential tephra fall in local communities. In fact, since the last ice age, the thickest tephra fall in the Mount Jefferson area, about 10 to 15 centimeters (4 to 6 inches), occurred from the eruption of ancient Mount Mazama that created Crater Lake about 7,600 years ago.

The accompanying maps (plate 2) indicate the annual probability of tephra fall affecting the central Oregon region from all major Cascade volcanic centers. The maps are based on the combined likelihood of tephra-producing eruptions 
occurring at Cascade centers, the relationship between thickness of a tephra-fall deposit and distance from its source vent, and regional wind patterns [8]. Probability zones extend farther east of the range because winds blow from westerly directions most of the time. One map shows annual probabilities for a fall of one centimeter (about 0.4 inch) or more and the other for a fall of 10 centimeters (about 4 inches) or more. The map pattern illustrates clearly the dominating influence of Mount St. Helens as a tephra producer. The area around Mount Jefferson has an annual probability of tephra fall of 1 centimeter ( 0.4 inches) or more of about 1 in 5,000 and an annual probability of a fall of 10 centimeters or more of about 1 in 10,000 or less.

\section{Hazard forecasts and warnings}

Scientists recognize several signs of impending volcanic eruptions. The upward movement of magma into a volcano prior to an eruption causes changes that can usually be detected by geophysical instruments and visual observation. Swarms of small earthquakes are generated as rocks break to make room for rising magma or as heating of fluids causes underground pressures to increase. Heat from the magma can increase the temperature of ground water and boost temperatures and steaming from fumaroles; it can also generate small steam explosions. The composition of gases emitted by fumaroles can change as magma nears the surface. Injection of magma into the volcano can cause swelling or other types of surface deformation.

A regional seismic network operated jointly by the U.S. Geological Survey and the Geophysics Program at the University of Washington can detect and locate earthquakes in the Mount Jefferson region. However, the region has experienced almost no detectable earthquakes during the two decades since the network was installed. The onset of earthquake activity would quickly gain scientists' attention. At monitored volcanoes similar to those in the Mount Jefferson region, a notable increase in seismicity has occurred weeks to months before the onset of eruptions.

An increase in seismicity would prompt deployment of additional seismometers to better locate earthquakes, establishment of a deformation network to detect slight ground movements, and monitoring of volcanic gases. Changes in some or all of these parameters might indicate intrusion of new magma into the volcano.

Periods of unrest at volcanoes are usually times of great uncertainty. Although outstanding advances have been made in volcano monitoring and eruption forecasting over the past few decades, scientists are often able to make only very general statements about the probability, type, and scale of an impending eruption. Precursory activity can go through accelerating and decelerating phases, and sometimes die out without leading to eruption. Government officials and the public must realize the limitations in forecasting eruptions and be prepared for such uncertainty.

\section{Protecting our communities and ourselves from volcano hazards}

Communities, businesses, and citizens need to plan ahead to mitigate the effects of future eruptions, debris avalanches, and lahars. Long-term mitigation includes using information about volcano hazards when making decisions about land use and siting of critical facilities. Development should avoid areas judged to have an unacceptably high risk or be planned to reduce the level of risk.

When volcanoes erupt or threaten to erupt, emergency responses are needed. Such responses will be most effective if citizens and public officials have an understanding of volcano hazards and have planned the actions needed to protect communities.

Because an eruption can occur within weeks to months of the first precursory activity and because some hazardous events can occur without warning, suitable emergency plans should be made beforehand. Although it has been a long time since Mount Jefferson has erupted and it is unknown when it may erupt again, public officials need to consider issues such as public education, 
communications, and evacuations. Emergency plans already developed for floods may apply, with modifications, to hazards from lahars. A map showing the shortest route to high ground will also be helpful.

The most important item is knowledge about volcano hazards and, especially, a plan of action based on the relative safety of areas around home, school, and work. Lahars pose the biggest sudden threat to people living or recreating in valleys that drain Mount Jefferson. The best strategy for avoiding a lahar is to move to the highest possible ground. A safe height above river channels depends on many factors including size of the lahar, distance from the volcano, and shape of the valley. For areas beyond the proximal hazard zone, all but the largest lahars will rise less than 30 meters (100 feet) above river level.

\section{References and additional suggested reading}

Blong, R.J., 1984, Volcanic hazards: Academic Press, Orlando, $424 \mathrm{p}$.

Conrey, R.M., 1991, Geology and petrology of the Mt. Jefferson area, High Cascade Range, Oregon: Ph.D. dissertation, Washington State University, Pullman, $357 \mathrm{p}$.

Francis, Peter, 1976, Volcanoes: Penguin Books, Middlesex, England, 368 p.

Hoblitt, R.M., Miller, C.D., and Scott, WE, 1987, Volcanic hazards with regard to siting nuclear-power plants in the Pacific Northwest: U.S. Geological Survey Open-File Report 87-297, 196 p.

Myers, B., Brantley, S.R., Stauffer, P., and Hendley, J.W., 1997 (revised 1998), What are volcano hazards?: U.S. Geological Survey Fact Sheet 002-97, 2 p.

Saarinern, T.F. and Sell, J.L., 1985, Warning and response to the Mount St. Helens eruption: State University of New York Press, Albany, 240 p.

Tilling, R.I., ed., 1989, Volcanic hazards: Short course in geology, vol. 1, American Geophysical Union, Washington, D.C., 123 p.

\section{End notes}

[1] The geologic data used in this report come largely from Conrey, R.M., 1991, Geology and petrology of the Mt. Jefferson area, High Cascade Range, Oregon: Ph.D. dissertation, Washington State University, 357 p. Other references used include Scott, WE, 1977, Quaternary glaciation and volcanism, Metolius River area, Oregon: Geological Society of America Bulletin, v. 88, p. 113-124; Beget, J.E., 1981, Evidence of Pleistocene explosive eruptions of Mount Jefferson, Oregon: EOS, v. 62, no. 45, p. 1089; O'Connor, J.E., Hardison III, J.H., and Costa, J.E., Debris flows from moraine-dammed lakes in the Three Sisters and Mt. Jefferson Wilderness Areas, Oregon: U.S. Geological Survey Open-File Report, in press.

[2] The proximal hazard zone was created by projecting energy cones described by $\mathrm{H} / \mathrm{L}=0.2$ from the summit of Mount Jefferson on a digital topographic base map of the Mount Jefferson area (see, for example, Malin, M.C., and Sheridan, M.F., 1982, Computer-assisted mapping of pyroclastic surges: Science, vol. 217, p. 637-640; Hayashi, J.N., and Self, S., 1992, A comparison of pyroclastic flow and debris avalanche mobility: Journal of Geophysical Research, vol. 97, p. 9063-9071; Iverson, R.M., Schilling, S.P. and Vallance, J.W., 1998, Objective delineation of lahar-hazard zones downstream from volcanoes: Geological Society of America Bulletin, vol. 110, p. 972-984). Here H is the vertical distance of descent from the summit, and $\mathrm{L}$ is the horizontal distance of travel from the summit.

Pyroclastic flows typically exhibit energy-cone slopes of about $\mathrm{H} / \mathrm{L}=0.2$. Debris avalanches of large volume (more than 100 million cubic meters) can exhibit lower energy-cone slopes than do pyroclastic flows (travel farther for a given drop), and most such far-traveled avalanches at Mount Jefferson would funnel from the proximal hazard zone into valleys encompassed within distal hazard zones.

[3] Descriptions of floods and lahars associated with emptying of moraine-dammed lakes at Mount Jefferson have been described elsewhere (O'Connor, J.E., Hardison III, J.H., and Costa, J.E., Debris flows from moraine-dammed lakes in the Three Sisters and Mt. Jefferson Wilderness Areas:

Oregon, U.S. Geological Survey Open-File Report, in press). These descriptions indicate that moraine-dammed lakes on Mount Jefferson contain less than 1 million cubic meters of water each. On the basis of this water volume, lake geometry, and the past behavior of dam-breach floods elsewhere (Walder, J.S., and O'Connor, J.E., 1997, Methods for predicting peak discharge of floods caused by failure of natural and constructed earthen dams: Water Resources Research, vol. 33, p. 2337-2348), we estimate that water discharges resulting from future failures of moraine dams on Mount Jefferson will probably not exceed 300 cubic meters per second (10,000 cubic feet per second). Flood magnitude might increase where substantial volumes of sediment are entrained to form lahars, but the resulting lahar volume is unlikely to exceed several million cubic meters. The 
resulting areas of downstream innundation will probably be smaller than those shown for the smallest (innermost) distal hazard zone shown on the map.

[4] Distal lahar hazard zones were constructed by assuming hypothetical lahar volumes of 20 million, 100 million, and 500 million cubic meters. Using published mathematical and digital cartographic techniques (Iverson, R.M., Schilling, S.P., and Vallance, J.W., 1998, Objective delineation of lahar-hazard zones downstream from volcanoes: Geological Society of America Bulletin, vol. 110, p. 972-984), these three volumes were used to compute the probable extent of inundation downstream from the proximal hazard zone. A volume of 500 million cubic meters is considered to represent the largest likely debris avalanche from Mount Jefferson, based on the following analogy to the 1980 debris avalanche at Mount St. Helens. The 1980 avalanche removed about 2,300 million cubic meters from an area on the north flank of the volcano with an average surface slope of 0.5 (about 30 degrees). The avalanche removed about $25 \%$ of the cone's volume above the altitude at which the failure plane intersected the lower north flank. In contrast to Mount St. Helens, Mount Jefferson is deeply eroded with very prominent buttresses, which seem unlikely to fail, and slopes greater than 0.5 are chiefly confined to the upper part of the volcano. Thus, there is less volume available (as compared to Mount St. Helens) to generate large debris avalanches. Assuming that the $25 \%$ value from Mount St. Helens applies to Mount Jefferson, we estimate that the volume of a large debris avalanche is likely to be no more than 500 million cubic meters. If the debris avalanche completely transformed into a lahar, the volume would be about 500 million cubic meters, which we feel is the largest volume that could be generated from a single landslide failure or explosive event. The smaller design volumes of 100 million cubic meters and 20 million cubic meters produce less extensive hazard zones.

[5] Personal communication, J.E. O’Connor, U.S. Geological Survey, Portland, Oregon.
[6] There are few data pertaining to the entry of lahars into lakes (see, for example, Pierson, T.C., 1985, Initiation and flow behavior of the 1980 Pine Creek and Muddy River lahars, Mount St. Helens, Washington: Geological Society of America Bulletin, vol. 96, p. 1056-1069.) A substantial body of work does exist regarding wave generation in water bodies by landslides and seismic ground displacement. The most pertinent work for present purposes is probably that done by Swiss investigators on landslide-generated waves (Huber, A., 1980, in Seen als Folge von Felsstürzen: Mitteilung Nr. 47 der VAW-ETH, Zürich, 222 p.; Huber, A., 1982, Impulse waves in Swiss lakes as a result of rock avalanches and bank slides: Proceedings of 14th International Congress on Large Dams, Q.54, R. 29, p. 455-476; Huber, A., 1997, Quantifying impulse wave effects in reservoirs: Proceedings of 19th International Congress on Large Dams, Q. 74, R.35, p. 563-581; Huber, A., and Hager, W.H., 1997, Forecasting impulse waves in reservoirs: Proceedings of 19th International Congress on Large Dams, C. 31, p. 993-1005; Müller, D.R., 1995, Auflaufen und Überschwappen von Impulswellen an Talsperren: Mitteilung Nr. 137 der VAW-ETH, Zürich, 297 pp.). Nonetheless, differences in the dynamic behavior of landslides and lahars make it difficult to apply the Swiss results with a high degree of confidence when we consider lahar entry into lakes. We have therefore applied the concepts developed in the Swiss work in a largely qualitative fashion.

[7] Information about Detroit Lake and Lake Billy Chinook, and about reservoir operations, comes from Johnson, D.M., Petersen, R.M., Lycan, D.R., Sweet, J.W., Neuhaus, M.E., and Schaedel, A.L., 1985, Atlas of Oregon lakes: Oregon State University Press, Corvallis, 317 pp.; and from personal communications with personnel of the U.S. Army Corps of Engineers and Portland General Electric in Portland, Oregon.

[8] Tephra-hazard maps were generated by a computer program developed by R.M. Hoblitt (U.S. Geological Survey, Cascades Volcano Observatory, 1996). 